\title{
Prevalence of Staphylococcus aureus, Escherichia coli and Salmonella spp. isolated from meat and cooked meat at Khon Kaen Municipality Schools
}

\author{
A Polpakdee*, S Angkititrakul \\ From 3rd International Conference on Prevention and Infection Control (ICPIC 2015) \\ Geneva, Switzerland. 16-19 June 2015
}

\section{Introduction}

Staphylococcus aureus, Escherichia coli and Salmonella spp. are important causes of enteric illness. Foods of animal origin have been consistently implicated as the main sources of enteritis in school children.

\section{Objectives}

The purpose of this study was to determine the prevalence of Staphylococcus aureus, E. coli and Salmonella spp. in meat and cooked meat.

\section{Methods}

The raw and cooked pork and chicken in the canteens from 11 Khon Kaen Municipality Schools (average age 10-16 year) were collected between February and March 2013. Fifty-three were from raw meat and 91 were from cooked meat. Salmonella spp., Staphylococcus aureus and Escherichia coli were detected by ISO 6579:2002, AOAC Official Method 998.08 (3M Petrifilm) and AOAC Official Method 2003.11 (3M Petrifilm), respectively.

\section{Results}

The results showed that the raw meats were contaminated with S. aureus, E.coli and Salmonella spp. 43.40\%, $62.26 \%, 56.60 \%$ and $25.27 \%, 43.96 \%, 7.69 \%$ in cooked meats, respectively.

\section{Conclusion}

The source for meat consumption should be from standard farms and slaughterhouses. In addition, hygienic kitchens, cooking skills, and healthy cooks are major factors for hygienic municipality school canteens, so that they are safe for school children consumption.

\section{Disclosure of interest}

None declared.

Published: 16 June 2015

References

1. Noi Thongsakulpanit and Supaporn Waeteewothajarn: Contamination of Microorganisms in Food, Water and Container in Food shop at Khon Kaen Municipality. Journal of the office of DPC 6 Khon Kaen 2002, 9:25-40.

2. Supaporn Waeteewothajarn and Noi Thongsakulpanit: Contamination of Salmonella in Pork and Chicken meat at market, Khon Kaen. Journal of the office of DPC 6 Khon Kaen 2002, 9:1-7.

doi:10.1186/2047-2994-4-S1-P114

Cite this article as: Polpakdee and Angkititrakul: Prevalence of Staphylococcus aureus, Escherichia coli and Salmonella spp. isolated from meat and cooked meat at Khon Kaen Municipality Schools. Antimicrobial Resistance and Infection Control 2015 4(Suppl 1):P114.
Submit your next manuscript to BioMed Central and take full advantage of:

- Convenient online submission

- Thorough peer review

- No space constraints or color figure charges

- Immediate publication on acceptance

- Inclusion in PubMed, CAS, Scopus and Google Scholar

- Research which is freely available for redistribution 